\title{
Two Rounds of Postwar Restitution and Dignity Restoration in the Netherlands and France
}

\author{
Wouter Veraart
}

The looting and systematic deprivation of the property rights of the Jewish population in the Netherlands and France during the years of occupation brought about a deprivation of dignity, since these measures were intended to hit these people in their capacities as legal subjects, destroying their abilities to take part in economic and social life. In the immediate postwar period, the restitution of property rights in both countries was closely connected and limited to an abstract conception of dignity restoration, understood as the renewed recognition of the dispossessed owners as free and equal citizen before the law. In the late 1990s, a new phase in the restoration of property rights took place on a much more collective and political level. In this second round of restitution, dignity restoration was directly connected with an explicit recognition of the particular, concrete suffering of the groups of victims involved.

\section{INTRODUCTION}

How should one respond to a massive, orchestrated deprivation of property rights when it is clear that this systematic dispossession has been an integral part of a gradual, deliberate process of exclusion and elimination of specific categories of people who are deemed to be less than human? Taking away one's property rights with the aim of excluding that person from public and economic life goes beyond dispossession, theft, or robbery. The systematic deprivation of property rights-spoliation, as it has often been called in the European context of World War II-of the European Jews during the years of Nazi occupation in the Netherlands and France (1940-1945) may serve as a paradigm example of what Bernadette Atuahene $(2014,26)$ understands as dignity takings: "dignity takings occur, when the state confiscates property from groups that have been dehumanized or infantilized."

Section II of this article takes a brief look at the dispossession of the Jews in the Netherlands and in France between 1940 and 1945, and points to some

Wouter Veraart, LLM (1971), M Phil, is a professor of legal philosophy at the Vrije Universiteit Amsterdam in the Netherlands. In 2005, Veraart obtained his PhD degree (cum laude) on "The Deprivation and Restitution of Property Rights During the Years of Occupation and Reconstruction in the Netherlands and in France." For this work and related publications he received in 2006 the Dirk Jacob Veegens Award from the Royal Dutch Society of Sciences (KHMW). In 2007, Veraart obtained a three-year grant on the topic "Time, Restitution and the Law" from the Netherlands Organisation for Scientific Research. In his inaugural lecture, "The Passion for a Mundane Legal Order," in 2009, Veraart focused on the legal consequences of forgetting and remembering as collective answers to injustice of the past. He can be contacted at w.j.veraart@vu.nl. 
differences in the way the deprivation of rights unfolded in both countries. Since the focus of this article is on dignity restoration, the question whether the dispossessions of the European Jews constituted dignity takings will be dealt with only summarily. Departing from the assumption that dignity takings did in fact occur with regard to the Jews in the Netherlands and in France between 1940 and 1945, this article's central research question revolves around the way dignity restoration was conceptualized and understood by leading actors in the field, first in the immediate postwar period in the 1940s and 1950s (Section III), and second in the 1990s and 2000s (Section IV).

Atuahene's (2014) concept of dignity restoration is multilayered. She understands dignity restoration as a process that seeks to remedy the denial of property, equal human worth, and autonomy by (1) offering sound mechanisms of property restitution or alternative compensation, (2) reinstating claimants "as respected members of the polity with voices worthy of hearing," and (3) by giving them agency in the process of restoration and also enabling them to reconnect with their communities (Atuahene 2014, 55).

This article further develops the concept of dignity restoration by showing that it can be differently understood and conceptualized in different historical contexts and at different points in time, which may have a substantial impact on the restitution process itself, on its evaluation, and on its possible outcomes. To make this point, I argue that the concept of dignity restoration is not fixed, but that its meaning is context dependent and has undergone a remarkable shift in the decades following the war.

In the first decade after the end of World War II, the governments of the Netherlands and France both implemented restitution policies in order to correct the wrongs committed. The core principles behind these complex restitution processes are briefly outlined in Section III and submitted to the following question: To what extent did these immediate postwar remedies amount to what Atuahene understands as dignity restoration?

In the late 1990s, both countries initiated a second round of restitution regarding the systematic dispossession of Jewish assets during World War II. How did this second round relate to the earlier restitution process? How was dignity restoration conceived of in the Netherlands and France in the late 1990s, when compared with the conception of dignity restoration in the immediate postwar period? These two questions are addressed in Section IV.

Section V contains some concluding remarks.

My description of the case study in this article is largely based on my earlier work as a legal historian in this field, flowing from research in historical archives and other primary sources. To develop the concept of dignity restoration further, I briefly elaborate (in Sections III and IV) on some philosophical ideas, especially on Seyla Benhabib's distinction between the "generalized other" and the "concrete other" (Benhabib 1992, 158-70), in order to clarify the two different paradigms of dignity restoration that appear to be applicable in this case. Therefore, in order to address my central question in a proper way, conventional research methods from legal history and legal philosophy are combined. 


\section{SYSTEMATIC DISPOSSESSION IN THE NETHERLANDS AND IN FRANCE (1940-1945)}

When does dispossession become a dignity taking or a legal injustice akin to a degradation of one's status as legal subject? The complex histories of dispossession of certain categories of people in the Netherlands and in France between 1940 and 1945 can count as clear examples of dignity takings. According to Atuahene's theoretical framework, dignity takings are (1) when a state directly or indirectly (2) destroys or confiscates property (3) from owners or occupiers (4) whom it deems to be subpersons (5) without paying just compensation or without a legitimate public purpose $(2014,26-34)$. Notwithstanding differences in the breadth and depth of dispossession in both countries, these five elements are clearly fulfilled in both cases. Both in the Netherlands and in France, the (occupied) state apparatus was the driving force behind the process of confiscating property rights (first and second elements) from targeted owners or tenants (third element). The overarching objective behind this orchestrated policy of dispossession, which occurred mostly without compensation (fifth element), was to deprive certain parts of the population of their legal status because they were considered to be subhuman (fourth element). ${ }^{1}$

The primary (although not the only) victims of these measures were those who the Nazis, according to their own definition, considered to be Jews. The objective was to exclude them from public, social, and economic life, and to hit them severely in their capabilities to act as responsible human persons. As Hannah Arendt (1975) and Raul Hilberg (1985) have shown, the targeted "killing" of "the juridical person in man" (Arendt 1975, 447) by a systematic deprivation of property rights (expropriation, in Hilberg's terms) must be understood as a necessary step in the multilayered process of "destruction" of the European Jewry by the Nazis and their helpers, accompanied or followed by deportation, concentration, and physical annihilation. Popular concepts such as confiscation, looting, theft, robbery, or expropriation do not capture this deliberate assault on the juridical person very well, as all these notions somehow suggest that material gain, greed, or profit seeking has been the ultimate goal. However, profit seeking was a factor as it triggered non-Jewish parts of the Dutch and French populations to take part in the looting operation as administrators, buyers, legal experts, stockbrokers, notaries, estate agents, or intermediaries, even if they did not share the Nazi ideology.

Before turning to the postwar restitution process in both countries, a few more details about the way the looting process unfolded in both cases may be helpful. ${ }^{2}$ Both countries were at least partly occupied during the war years and so the systems of dispossession were to a large degree state owned and legalized. In the legalization of the process, the French Vichy government in the southern part of Franceheaded by the French marshal Pétain and heavily collaborating with the Nazis until its annexation by the Germans at the end of 1942-went even further than the German military authorities in the French occupied zone in the north.

1. See also Atuahene $(2014,31)$, where she treats the "Nazis' belief that the Jews were vermin" as one of her key examples of "dehumanization."

2. The remainder of this paragraph is based on Veraart $(2011,22-24)$. 
In the Netherlands, the German administration during occupation took on a civilian form. Between 1940 and 1943, the Reichskommissar of the Dutch occupied territories, Arthur Seyss-Inquart, a skilled Austrian jurist, issued thirteen decrees specifically designed to deprive Jews in the Netherlands of more or less all their assets: not only their movable and unmovable assets, but also all kinds of financial rights, such as securities, mortgages, insurance policies, and claims against third parties. The German authorities used different private institutions such as banks ("looting institutions," as they would be called in the postwar period) to deprive the Jewish population of its assets, with the most notorious institution deliberately using the same abbreviated name (Liro) as that of an existing Dutch-Jewish bank (Lippmann, Rosenthal, \& Co.) in order to appear more trustworthy. Jews were obliged to deposit all their financial assets and valuables at this institution. Liro then sold these assets without the permission of the former owners and without properly compensating them. Renowned Dutch institutions, such as the Dutch central bank, which was controlled by the Germans during the war, and the Dutch Stockbrokers' Association, heavily collaborated with Liro in this process.

The extent of the process of property rights deprivation in the Netherlands is reflected in the fact that in the Netherlands only 17 percent of its Jewish inhabitants survived the war years, as opposed to 75 percent in France (Dreyfus 2003, 42). The process of dispossession in the Netherlands consequently exceeded the dispossession in France in both breadth and depth. In France, the process did not cover the entire spectrum of property rights: there was no systematic deprivation, for example, of insurance policies and mortgages. Furthermore, the deprivation of property rights in France took place at a slower pace than in the Netherlands. The so-called aryanization of Jewish enterprises by the notorious General Commission of Jewish Affairs (a subdepartment of the Vichy administration) was carried out in strict compliance with legal forms; specific looting institutions, such as Liro in the Netherlands, did not exist.

The English summary of the final report of the French Mattéoli commission ${ }^{3}$ refers to "the inherent slowness à la française of the administration, which was extremely bureaucratic. The greatest paradox is evident in the blatant clash between its legal formalism and the aim which it was pursuing, i.e. spoliation, and even outright theft" (Mattéoli 2000b, 21). Vichy France tried to use the aryanization of Jewish enterprises as a means of fostering French economic interests (Verheyde 1999, 30-31), more or less in the same spirit as Dutch stockbrokers and estate agents have tried to keep the profits of the aryanization in Dutch hands. But unlike the situation in the Netherlands, the aryanization process in France was far from complete by the time of the liberation. The percentage of unfinished filesconcerning financial assets, businesses, and property holdings still under administration and not yet liquidated or sold-varied from 53 percent in the Seine region to 58 percent in the entire northern zone and an estimated 60 percent in the southern part of France (Mattéoli 2000b, 22).

3. The Study Mission on the Spoliation of Jews in France, chaired by the French politician Jean Mattéli, was set up in 1997 by the French government to research the dispossession (spoliation) and the postwar restitution of Jewish assets. 


\section{RESTITUTION AND DIGNITY RESTORATION IN THE IMMEDIATE POSTWAR YEARS}

How did the post-war French and Dutch governments respond to the legal injustice of the war years? Preparation for the legal and economic postwar restoration in the Netherlands and France had already started in the middle of the war, in London, where the Dutch government in exile and the French National Committee around General Charles de Gaulle prepared for return. On January 5, 1943, together with fifteen other allied governments, they proclaimed the Inter-Allied Declaration Against Acts of Dispossession Committed in Territories Under Enemy Occupation or Control (Inter-Allied or London Declaration), issuing a formal warning "that they intended to do their utmost to defeat the methods of dispossession practised by the Governments with which they are at war," reserving "all their rights to declare invalid any transfers of, or dealings with property, rights and interests of any description whatsoever which are, or have been situated in the territories which have come under occupation or control ... of the Governments with which they are at war."

This warning also applied to transfers "apparently legal in form, even when they purport to be voluntarily effected" (Veraart 2011, 24-25; Campfens 2015, 1617). What did the French and the Dutch legal frameworks for postwar restitution promised in the Joint Declaration look like? Elsewhere, I have pointed to some striking differences in the way the Dutch and French legislators and postwar policymakers approached the issue (Veraart 2011). In the following paragraphs, I highlight some of these differences, directly basing myself on the main conclusions of my earlier research in this specific field (Veraart 2005, 545-51; 2011, 25-27). Subsequently, I explore the extent to which the French and Dutch ways of processing restitution in the late 1940s and 1950s correspond to Atuahene's conception of dignity restoration.

Let us start, first, with a brief description of the Dutch approach to restitution in the immediate postwar years. The guiding principles with regard to restitution have been implemented in the Dutch Decree on the Restoration of Legal Relations (E 100), promulgated by the Dutch exile government on September 17, 1944. This decree departed from the presupposition that the violations and corruptions of legal relations under German occupation had been so complex that they could be repaired only on the basis of common sense in a flexible and pragmatic way. The drafters of E 100 believed that the exceptional situation caused by the German occupation could be undone only by an exceptional institution, equipped with exceptional powers. This became the Council of Restoration of Rights, which consisted of four divisions: a Judicial Division-the only independent division acting as a special court in restitution matters - and three administrative entities, the Custodian Division, the Immovable Property Division, and the Securities Division, whose decisions could be appealed to at the Judicial Division. Regarding the verdicts of the Judicial Division, the possibility of appeal or cassation was excluded, not only to speed up the process, but also to prevent too much legal discussion.

The Judicial Division had to apply open standards of equity and reasonableness within the special circumstances of each case. If a transaction was based on racist legislation retroactively declared null and void by the Dutch government (as it did 
in its Decree E 93 on September 17, 1944), a "failure to intervene in the transaction" was presumed to be unreasonable according to Section 25 of Decree E 100, although bringing about restitution was certainly not obligatory (Veraart 2011, 2526). Judges were not supposed to behave like black-letter jurists, but rather like good men or arbitrators. The Dutch legal framework also provided for some rules to protect the recipients of despoiled property against claims from the former owners. They could keep the property if they made a reasonable case that they acquired it in good faith.

The wide discretion on the part of the Judicial Division led to a certain degree of randomness and unpredictability in the Judicial Division's rulings. The (heirs of the) dispossessed owners could not rely on getting back their property by the operation of law. For each property they were deprived of, they were forced to begin a legal battle with the current possessor of that property, with the non-negligible chance that they would not win and be left with uncertain claims against the assets of German looting institutions that had cashed in on the goods during the years of occupation. Moreover, the acquirers of looted property who were able to demonstrate their good faith plausibly enjoyed full protection against restitution actions and damages actions, a protection that went a good deal further than that offered by Dutch civil law (Veraart 2005, 546-47).

In the postwar period (1945-1952), the Dutch Minister of Finance, Lieftinck, got a strong hold on the nonjudicial divisions of the Council of Restoration of Rights. He used the restitution machinery mainly to pursue the financial interests of the Dutch state in order to reconstruct the economy, even if this policy conflicted with the interests of the dispossessed Jewish community. He often claimed that the Germans, not the Dutch, had been responsible for the dispossession of the Jews. This position was hard to maintain when it became clear that renowned Dutch institutions, such as the central bank and the Stockbrokers' Association, had collaborated with the Germans in the process of dispossession. However, Lieftinck, with his mind set on the social-economic reconstruction of Dutch society in general, did his utmost to protect Dutch financial institutions against claims during the postwar period. As a result, the only institution trusted by the Jewish community became the independent Judicial Division of the Council of Restoration of Rights (Veraart 2005, 546; 2011, 26).

In the early 1950s, as a consequence of some principled decisions of the Judicial Division, an out-of-court settlement between the Dutch government, the Stockbrokers' Association, and representatives of the Jewish community, and Lieftinck's departure as minister, the tides turned in favor of the dispossessed Jewish owners. Original Jewish owners who were left with claims on the German looting institutions received much higher compensation (between 75 percent and 90 percent of the value) than anyone had anticipated. In general, the outcomes of the restitution process in the 1950 s exceeded expectations and were perceived by the Jewish community at the time as a victory (or at least as acceptable) after a long, gruesome legal battle (Veraart 2011, 27).

In sharp contrast with the Dutch government in exile, the Free French rallying around General de Gaulle between 1940 and 1944 did construct a legal framework of restitution that conformed, as much as possible, to basic principles of the rule of 
law and the droit commun of the French Code Civil. Unlike in the Netherlands, the restitution was not left to an extraordinary institution in which the executive and judicial functions sometimes overlapped, but was placed under the normal (purged) judiciary, including possibilities of appeal and cassation. It thus became a particular, but integrated, element of French legal practice on which the French government, due to the separation of powers, could exert no direct influence (Veraart 2005, 548-49).

Also from the perspective of substantive law, the French restitution legislation stood in contrast to the Dutch. Instead of open-ended standards, with reasonableness playing a central role, in its main restitution decree of April 21, 1945, the French restitution legislator took the opposite approach, assuming strict and specific rules that in essence entailed that virtually all transactions that had taken place under duress, working around the owners, were legally invalid and, without qualification (although with a few notable exceptions), all transactions had to be reversed. Transactions with an apparent voluntary character, having been effected by the owner, could be reversed if that owner had belonged to one of the groups faced with systematic persecution and measures of dispossession. In such cases, the owner profited from a suspicion of duress, which the acquirer could then later refute. In addition, good faith on the part of the acquirer could not-with a few exceptions, such as in the case of stocks and bonds being sold at the stock exchange-affect the original owner's restitution, neither in the case of forced nor in apparently voluntary transactions (Veraart 2005, 549-50).

The result of all this was that right from the early stages, the dispossessed community in France could be reasonably certain of getting its property back. Although restitution in France did take longer than expected, the entire process proceeded relatively trouble free. Also in contrast to the Netherlands, victims of dispossession were better informed than in the Netherlands. A special body appointed by the French government, the Service des Restitutions, verified whether the dispossessed were taking steps to obtain restitution, and where necessary, encouraged them to do so (Prost, Skoutelsky, and Étienne 2000, 65-67, 77-83; Veraart 2005, 550).

In what way did the Netherlands and France provide for dignity restoration in the 1940s and 1950s? As outlined in the introduction to this article, Atuahene $(2014,55)$ understands dignity restoration as a process that seeks to remedy the past denial of property, equal human worth, and autonomy of the dispossessed claimants by (1) offering sound mechanisms of property restitution or alternative compensation, (2) reinstating claimants "as respected members of the polity with voices worthy of hearing," and (3) giving them agency in the process of restoration and also by enabling them to reconnect with their communities.

Despite the remarkable differences in vision and guiding principles as described above, it is clear that the restitution process in both countries offered elaborated legal mechanisms of property restitution or alternative compensation (first element), although the French restitution scheme was more rewarding and sensitive to the interests of the original owners than the Dutch scheme. Moreover, in both cases, the restitution process served more than only material values. The access to an independent court in both countries symbolized the renewed legal recognition of the dispossessed as free and equal citizens whose voices were respectfully listened to 
by independent legal officials (second element). By giving the dispossessed the opportunity to stand up for their rights, by reinstating them as rightful claimants, agency was restored to them (third element).

From a victim perspective, the design of the restitution process in the Netherlands was less welcoming than in France, leaving a lot to fight for and even more room for frustration and disappointment-the legal road to justice being occasionally blocked by a very powerful Minister of Finance, who prioritized the economic reconstruction of the country-and much uncertainty in terms of outcome. The French approach was more receptive toward the immaterial side of the loss that the victims of dispossession had suffered. The principled approach guaranteeing the undoing of most forced transactions by operation of law proves this, as do the activities of the Service des Restitutions, the public institution monitoring the restitution process, proactively looking for possible claimants and directly communicating with them. Its director, Emile Terroine, a former resistance fighter, referred to the French restitution process as "a labour both of justice and humanity, which moral and political meaning far transcends the material values in question"4 (Mattéoli 2000a, 13).

If we adhere to Atuahene's definition of dignity restoration as seeking "to rehabilitate dispossessed populations and reintegrate them into the fabric of society through an emphasis on process" (Atuahene 2014, 58), it is not difficult to see that the French approach was more rewarding than the Dutch one. There are factors that may explain, although not justify, this situation. First, the German occupation in the Netherlands only ended in May 1945, leaving the Dutch population famished and demoralized, the economy devastated, and the state bankrupt. The French came out of the war in relatively better shape, with the economy less fragile, the population less victimized, and with an upbeat leader, de Gaulle, who time and again claimed moral and political victory, promising to undo the injustices committed by the "so-called government-of-fact of Vichy"-that is, in self-assured denial of Vichy's legal existence (Veraart 2011, 33). Second, as indicated, the dispossession and persecution of the Jews in the Netherlands had been more intense, comprehensive, and destructive than in France, making the problems in the Netherlands more complex and harder to resolve.

However, notwithstanding the telling differences between France and the Netherlands in terms of legal framework, process, and communication, both approaches toward restitution were based on the same guiding principle. That principle was the idea that the discriminatory and dehumanizing practices of the Nazis could be answered only by a restoration policy in which no distinction between (categories of) citizens was made. It was considered of prime importance that, despite their unique war experience, the Jewish members of the population (and a few other persecuted groups) did not receive any special treatment (Bossenbroek 2001; Andrieu 2011, 14; Piersma and Kemperman 2015, 109-10). The restoration of the dignity of Jewish victims of dispossession and persecution was firmly and solely based on the (renewed) recognition of their status as fully fledged legal subjects, who were enabled to claim their property rights just like every other citizen.

4. "Pour moi, la restitution des biens spolié aux israélites est une oeuvre à la fois de justice et d'humanité dont la signification morale et politique dépasse de beaucoup les valeurs matérielles en cause.” 
Shimmering through this basic principle is a philosophy of Kantian right, promising emancipation from slavery and oppression by the (renewed) attribution of fundamental freedoms and equal rights. This ideal embraces a generalized conception of citizenship, abstracted from one's particular circumstances, experiences, emotions, or other characteristics. The ultimate answer to the horrendous crimes based on the racist ideology of Hitler's National Socialism was somehow believed to reside in the reestablishment of a political society based on legal equality, nondiscrimination, and the rule of law (the legality of the French republic, or the democratic rechtsstaat of the Netherlands). Within this Kantian paradigm, there was no room for collective pity or public recognition of the particular suffering of the Jewish communities in both countries.

The view that dignity restoration revolved around the formal recognition of many different victims, not as victims but as free and equal subjects in the legal community, was mirrored by the fact that at the time of the liberation in 1944 and 1945, both in the Netherlands and in France, the reception of those returning from the concentration camps was cold and formalistic (Weil-Curiel 1945; Citroen 1999). This so-called cold shower continued for many years. Pieter Lagrou concludes in his comparative historical study on the legacy of Nazi occupation in Western Europe that "[i]n the austere reconstruction ethic that dominated Dutch society in the first two post-war decades, the war was presented as an ordeal that had strengthened social cohesion and national identity. This anonymous and genuinely 'national' memory was harsh towards those who had suffered more and suffered differently" (Lagrou 2000, 293).

In the case of France, Lagrou draws a comparable, albeit slightly different, conclusion. The strong antifacism in the immediate postwar years, epitomized by de Gaulle and others (such as the French communist party), worked as a "universalizing device" with which a number of victims of Nazi persecution could positively identify, distancing themselves from their unspeakable war experience: "[T]he identification with anti-fascism was a means of overcoming the appallingly arbitrary affliction that had hit them, a way to take possession of their own destiny, a retrospective revenge on an inhuman enemy" (Lagrou 2000, 260).

In the same vein, in the Netherlands, Dutch-Jewish lawyers, who were waging the legal battles on behalf of the dispossessed Jewish community against the Dutch state and a number of powerful financial institutions, explicitly did not plea for recognition of the particular suffering of their clients. On the contrary, they positively identified with the paradigm of abstract legal equality, and urged that their clients be taken seriously in their rightful demands and be treated with the equal dignity to which every legal subject in the Netherlands was formally entitled. Their main frustration between 1945 and the early 1950s was that, notwithstanding this promise of legal equality, they still were not treated on an equal footing, since the Dutch government, on different occasions, prioritized the economic reconstruction of the Netherlands at the expense of the rightful claims of those who had been systematically deprived of their assets (Veraart 2005, 77).

\section{RESTITUTION AND DIGNITY RESTORATION IN THE NETHERLANDS AND FRANCE IN THE 1990S}

In the 1940s and 1950s, the predominant conception of dignity restoration corresponded with what the social philosopher Seyla Benhabib has defined as 
dignity of the "generalized other." In this conception, according to Benhabib (1992, 159), what constitutes moral dignity "is not what differentiates us from each other, but rather what we, as speaking and acting rational agents, have in common." In the 1990s, when issues around restitution of property rights with regard to World War II quite suddenly reappeared in many countries in Europe, this formal, abstract conception of dignity no longer prevailed. This time, another conception of dignity became dominant and determined the way the (postwar history of) restitution of property rights was understood and evaluated.

According to this second conception, dignity inheres in "concrete others." Benhabib explains that in this conception, the moral dignity of individuals derives from their concrete histories, particular identities, and social-affective constitutions (Benhabib 1992, 159; Bernstein 1995, 151). In other words, this second conception of dignity demands that we recognize each other in our particularities, in those things that differentiate us from all others-especially in our singular histories of suffering. In light of this second conception of dignity, restitution gained a different meaning. In sharp contrast to the immediate postwar period, in the 1990s restitution and the public recognition of particular suffering became directly and inexorably linked—with the memory of the Holocaust taking center stage (Diner 2007, 14, 19).

This remarkable shift has been noticed more than once. It is reflected in the way war trauma has been dealt with in postwar Europe and in the United States (Fassin and Rechtman 2009, 15). In a recent study of the politics of war trauma in eleven European countries, Jolande Withuis and Annet Mooij conclude that (speaking of the Netherlands) "adaptation" to the new normality, which was expected from all war victims in the austere reconstruction period in the 1940s and 1950s, was replaced by public "recognition" of particular forms of victimhood in the 1970s and 1980s (Withuis and Mooij 2010, 215). In a similar vein, with regard to the French restitution policy in the 1990s, the French historian Claire Andrieu concludes: "Because the Shoah has come to epitomise evil, public policy can now focus on this category of war victims without appearing to deviate from the principle of equality before the law in financial matters. Restitution is now seen as a form of moral reparation rather than a mere return of assets to legitimate owners" (Andrieu 2011, 16-17).

In the context of this article, it is not possible to do justice to the complex history of restitution of property rights in Europe in the 1990s and the first years of the twenty-first century. ${ }^{5}$ Here, it suffices to say that different factors, such as the end of the Cold War, the end of apartheid in South Africa, and the sudden propagation of the memory of the Holocaust on a global level (fifty years after the defeat of Nazi Germany) contributed to a strong public interest in the way European countries had organized the restitution of Jewish assets in the decades after the war (Maissen 2005, 87-94; Veraart and Winkel 2011). In the Netherlands and France, the establishment of historical commissions of inquiry into the dispossession and postwar restitution of Jewish assets followed after the global outcry caused by the discovery of so-called dormant (unclaimed) bank accounts in Switzerland belonging to Jewish clients who had perished during the war.

5. For in-depth studies, see Maissen (2005) and Unfried (2014), both in German. 
The new conception of dignity restoration of the 1990s colored the evaluations of the earlier round of restitution in the 1940s and 1950s and elicited new restitution measures. In the first place, the new paradigm became the moral yardstick according to which, retrospectively, the restitution process in the 1940s and 1950s was measured. As explained above, in the earlier prevailing paradigm, dignity restoration was understood in terms of a Kantian, formal return to the dignity of free and equal citizenship. The restitution of property rights reconstituted the dispossessed owners in their abstract dignity as legal subjects, by offering them the opportunity to reclaim their property rights before an independent judiciary. However, in the 1990s, the prevailing conception of dignity restoration no longer abstracted from the particular experiences and identities of different groups of war victims but, on the contrary, embraced them. The idea that dignity could be restored without public recognition of the particular suffering of concrete victim groups was clearly abandoned.

There are different ways to illustrate this phenomenon. Starting in the Netherlands, one example is the way the Dutch government offered apologies when responding to the conclusions of the final reports of different Dutch commissions of inquiry into the deprivation and postwar restitution of (mostly) Jewish assets in a letter to Dutch Parliament of March 21, 2000. In the beginning of this letter, the Dutch government "fully recognizes - looking back with the knowledge and eyes of today-that there has been too much formalism, bureaucracy and especially bleakness (kilte) in the restitution process [in the 1940s and 1950s]. For this, the government expresses sincere regret and offers apologies to those who then suffered, without presupposing any wrong intentions among those who bore responsibility" (Letter of the Prime Minister .. . 2000).

Another example is the following criticism of the Dutch-Jewish historian Isaac Lipschits with regard to the Dutch restitution process in the first decades after the war: "The [postwar] government claimed that, while during the war a major distinction had been made between Jews and non-Jews, this should no longer be the case. This seemingly egalitarian approach was actually highly discriminatory because, during the war, the Jews were persecuted as Jews not Dutchmen. ... When the Jews returned, or came out of hiding in 1945, their experiences and circumstances were so different from a normal situation that they should have been treated differently. The Jews had undergone a disaster which was ... radically different from the experiences of the average Dutchman" (Lipschits 2003, 180). These fierce, present-day criticisms of the cold formalism and legal egalitarianism of the postwar restitution process derive their persuasive force from the newly accepted conception of dignity restoration.

Both the Dutch government and Lipschits suggest that the Dutch restitution process in the 1940s and 1950s could and should have been executed with less formalism and with more specific attention to the particular experiences and circumstances of the Dutch Jews. In other words, they propose a tailored, understanding, victim-group-oriented approach, knowing that this approach, in light of the thenprevailing conception of dignity restoration - in which formalism and abstract legal egalitarianism were generally accepted as virtues, and not as vices-would have been nearly impossible to adopt.

In France, the scales were reversed on July 16, 1995, when President Jacques Chirac in a historic speech deeply apologized for the active role of French citizens and the French state (Vichy) in the deportation of tens of thousands of French and 
foreign Jews during World War II and declared France's everlasting debt toward those who perished (Fette 2006). During his speech, Chirac stated: "Recognize the wrongs of the past, and the wrongs committed by the State. To hide nothing from the dark hours of our history, it's simply to defend an idea of Man, of his liberty and his dignity." 6 The contrast with de Gaulle's attitude is striking. De Gaulle, in express denial of Vichy's legal existence, directly connected restitution and dignity restoration to the reestablishment of the legality of the French republic. Chirac's apology inaugurated a new round of restitution, in which the particular suffering of the Jewish victims could be publicly recognized and taken into account (Andrieu 2003, 117; 2007, 141-42; Unfried 2014, 149-50, 265-66).

The restitution debate in France and the Netherlands in the 1990s was primarily focused on "gaps and deficiencies" (Unfried 2014, 202) in the earlier restitution process, on so-called unfinished business (Eizenstat 2003) and took place under increasing international pressure and scrutiny, in particular from the United States and NGOs such as the World Jewish Congress in New York. However, it was not simply a matter of looking for deficiencies and imperfections. Through the normative lens of the 1990s, some of the restitution outcomes that were taken for granted or even hailed as victories by Jewish claimants in the 1940s and 1950s transformed into cases of clear injustice within the much more victim-oriented approach of the 1990s.

For example, the legal fact that heirless or otherwise unclaimed assets belonged to the state, which was undisputed in the 1940s and 1950s, was no longer tolerated in the 1990s. Within the old paradigm, the dispossessed individuals were restored in their dignity by their reintegration in the collective of the nation-state; therefore it was the state, and not a particular community, that was entitled to heirless assets. This legal arrangement had never been questioned in the 1940s and 1950s. In the 1990s, however, this practice was no longer morally accepted. Not the state, but the Jewish communities within the state (and partly abroad) came to be seen as the rightful heirs of originally Jewish assets for which no legal owner could be found (Unfried 2014, 480-81). As a consequence, on the basis of this new conviction, both the Dutch ${ }^{7}$ and French ${ }^{8}$ governments paid large amounts of compensation to the local Jewish communities to correct this wrong, and other perceived wrongs, in

6. "Reconnaître les fautes du passé, et les fautes commises par l'Etat. Ne rien occulter des heures sombres de notre histoire, c'est tout simplement défendre une idée de l'Homme, de sa liberté et de sa dignité." Text available at http://www.lemonde.fr/societe/article_interactif/2007/05/15/les-discours-de-jacqueschirac_910136_3224_2.html.

7. In 2000 , the Dutch state paid a total amount of fl. 400 million ( 186 million euros) in compensation, Dutch insurance companies paid fl. 50 million, Dutch banks fl. 50 million, and the Amsterdam Stock Exchange fl. $264 \mathrm{M}$; altogether a total sum of 764 million Dutch guilders (347 million euros) was transferred to the public Maror Compensation Fund (Maror) in which the Dutch Jewish community was represented. Maror used the money primarily for individual compensation to Jewish victims; additionally, the money was used for collective purposes serving the Jewish community in the Netherlands and abroad (Staal 2008, 233-49).

8. From 1999 until the end of 2010, the Commission for the Compensation of Victims of Spoliation (CIVS), established and funded by the French state, paid almost 500 million euros (Unfried 2014, 468) in individual compensation, mostly related to previously unclaimed property (Andrieu 2007, 138-39). Additionally, in 2000, the French state paid 394 million euros to the Foundation for the Remembrance of the Shoah (Fondation pour la mémoire de la Shoah), whose mission was to carry out research and express solidarity with regard to victims of persecution and anti-Semitic measures during World War II (Andrieu 2007, 139). 
the earlier postwar restitution process (Andrieu 2007, 138-39; Staal 2008, 233-49; Unfried 2014, 468; see also Letter of the Prime Minister ... 2000).

Another notable change occurred both in the Netherlands and in France in the 1990s. Not only the grounds for compensation were shifting from a legal, civil law perspective to a moral and politicized perspective-in which statutes of limitation could be lifted and the finality of earlier legal verdicts and legal settlements could be questioned-but also the group of people entitled to restitution underwent a transformation. Unlike in the 1940s and 1950s-where all rightful owners were legally restored in their property rights or compensated on the merits of their individual claims, irrespective of their personal war experiences or type of victimhoodin the late 1990s and early 2000s, compensation was also offered to certain categories of people on the basis of their belonging to a particular category of victims (Jewish victims or Roma and Sinti victims, etc.), while the specifics of their individual claims were deemed to be (much) less important. In the Netherlands, for example, in consecutive rounds between 2000 and 2003 lump-sum amounts totaling around 10,000 euros were paid to Jewish survivors of World War II who resided in the Netherlands during World War II or to their widows or widowers or their children, provided they applied for compensation before December 31, 2001. ${ }^{9}$ In France, the Commission for the Compensation of Victims of Spoliation (CIVS), established in 1999 and funded by the French state, operated in a similar fashion by applying an extreme relaxation of the rules of evidence in the handling of individual claims of victims of anti-Semitic legislation or their heirs (Unfried 2014, 46569). In one of her evaluations of the recent French restitution process, the French historian Claire Andrieu concludes: "Taking into account the generosity of the calculations that both the Mattéoli Commission [the French historical commission of inquiry, WV] and the CIVS use as their basis, and of the financial endowment of the Fondation pour la Mémoire de la Shoah, the rate of 'restitution' is quite possibly higher than 100 percent" (Andrieu 2003, 115; 2007, 140).

In short, in the 1990s, restitution became linked to the recognition of collective identities of victim groups and turned into a strongly politicized phenomenon. In the case of the Jewish assets, negotiations mainly took place outside the courtroom between representatives of the Jewish communities, representatives of the Dutch or French state, and a number of private financial organizations, such as insurance companies and banks. Whereas both states at first somehow successfully tried to steer away from US pressure and were focused on solving the issue within their own national boundaries, in the end both states could not ignore its global aspect, or mounting political, economic, and legal pressure, in particular from the United States.

Finally, with reference to newly discovered gaps and deficiencies in the restitution process in the 1940s and 1950s, large amounts of money were paid by different parties, often accompanied by public apologies expressing regret and guilt for the suffering caused both during the war and in the immediate postwar past. These reparations were often paid to public funds in which the Jewish communities had a

9. The history of these payments by the Dutch Maror Compensation Fund is very complex. For more details, see Staal $(2008,311)$. 
clear voice or representation. The money has been used to subsidize all kinds of purposes related to collective (cultural) Jewish life and the memory of the Shoah.

The most substantial part has been used for the compensation of individual claimants, by a system of redistribution on the basis of the claimant's recognized belonging to the category of Jewish victims (or by being a heir), in general without much scrutiny as to the legal specifics of each and every individual case. In short, the so-called corrective justice mechanisms of the 1940s and 1950s, operating on the basis of precise legal entitlements of individual claimants (and without paying attention to their collective identities), were replaced by more generous, but much less specific mechanisms of distributive justice in the 1990s and 2000s (Andrieu 2011, 19; Unfried 2014, 156-57) according to which one is entitled to compensation because one belongs to a certain recognized category of victims.

The amounts of money transferred to collective entities had a basis in documented gaps and perceived errors in the postwar restitution process, but the exact magnitude of the amounts had been the uncontrollable outcome of a process of negotiations between a large number of stakeholders. In the 1990s and the beginning of the 2000s, restitution lost much of its legal force (as it had in the 1940s and 1950s), but acquired a much more directly political and symbolic meaning. It came to be understood as a bridge toward recognition and reconciliation between states, financial institutions, and Jewish communities, locally and abroad (Veraart 2015, 218-219).

\section{CONCLUSION}

This article has departed from the assumption that the deprivation of property rights of the French and Dutch Jews during the German occupation of France and the Netherlands in World War II (1940-1945) was a quintessential case of a dignity taking (Atuahene 2014, 21): the massive deprivation of property rights, directly or indirectly perpetrated by the (occupied) state, was intended to dehumanize the Jewish owners, to hit them in their capabilities as responsible persons by excluding them from social and economic life; an important step in a bigger process leading to physical extermination. The focus of this article has been on dignity restoration: its main purpose was to show that the process of dignity restoration in this highly complex case has been a multilayered phenomenon in which, at two different moments in recent history, two different conceptions of dignity restoration prevailed.

In the first phase, during the years of reconstruction in western Europe in the 1940 s and 1950s, the restoration of the dignity of Jewish victims of dispossession and persecution was connected to their renewed recognition as fully fledged legal subjects within the collective of the national state. As respectable legal subjects, Jewish former owners were enabled to stand up for their property rights before an independent judiciary, just like every other citizen. Within this common framework, the French approach toward restitution was better suited to cater to the victims' needs than the Dutch one. However, notwithstanding noteworthy differences of the restitution process in both countries, the dignity restoration of the Jews in 
the 1940s and 1950s was based on their assimilation, on those characteristicsbeing a free and equal person, a responsible legal subject, and the like-which they shared with all other citizens. Consequently, both in France and the Netherlands, there was hardly any room for public recognition of the particular suffering of the Jewish communities in these austere years.

In the 1990s, on the contrary, restitution was directly linked to the memory of the Holocaust, to the explicit recognition of the incomparable ${ }^{10}$ suffering of the Jewish community during and after the war, and to apologetic expressions of guilt and regret. Dignity restoration in the 1990s and 2000s is no longer effected by pointing to the equal rights of Jews and non-Jews as equal citizens within the national state (Brown 1995, 56). In the 1990s, it was no longer the collective of the nation-state, but the particular Jewish community that was seen as the rightful collective heir to claims unaccounted for. Corrective justice on the specific merits of each case in the courtroom on the basis of abstract legal principles as happened in the 1940s and 1950s was replaced, in the 1990s and early 2000s, by elements of distributive or rough justice toward specific categories of victims on the basis of group membership as an outcome of political negotiations (Unfried 2014, 502; Ruppert 2015). The formalistic legal approach, with its restrictions, final verdicts, and statutes of limitation, has given way to a much broader moral-political recognition of particular forms and categories of victimhood, in which statutes of limitations have been lifted and the injustice of the past has been addressed with a novel eye. As a consequence, the moral approach of the 1990s and early 2000s is more partisan and less precise than the legal approach of the 1940s and 1950s.

This article has highlighted two types of dignity restoration that have been operative at different time periods in the case study. Both ways of dealing with the unjust past have their merits and weaknesses. On the one hand, it is obvious that the abstract conception of dignity restoration of the 1940s and 1950s failed to recognize, in Seyla Benhabib's terms, "that every generalized other is also a concrete other" (Benhabib 1992, 165). In other words, dignity restoration with a sole focus on the reestablishment of someone's dignity as a responsible legal subject, although very important, may not be sufficient if there is no attention at all for her or his particular life story as a finite, embodied, individual. ${ }^{11}$ On the other hand, if we make the dignity of the concrete other into our guiding point in dignity restoration, we run the risk of becoming discriminatory and partisan, and may nourish competition and envy between different victim groups. As Benhabib also writes: "without the standpoint of the generalized other, a political theory of justice suited for modern, complex societies is unthinkable" (Benhabib 1992, 164). Benhabib is looking for a moral theory that "allows us to recognize the dignity of the generalized other through an acknowledgment of the moral identity of the concrete other" (Benhabib 1992 , 164). In that light, the two consecutive rounds of dignity restoration in the Netherlands and France may be understood mutually to reinforce and supplement

10. In this regard, the uniqueness of the Holocaust is sometimes emphasized (Margalit and Motzkin 1996).

11. In the 1940s and the 1950s, these individual life stories were addressed in court, but only as far as necessary for the legal assessment of the facts relevant to the restitution claims. 
each other. What this complex case then shows is that only one round of dignity restoration may not be enough. Another time may add another layer. New generations may not only try to repair the loopholes, mistakes, and deficiencies of previous generations, but will also find ways to redefine what dignity restoration means for them and then write postwar history another time, but with a different focus.

\section{REFERENCES}

Andrieu, Claire. 2003. Zweierlei Entschädigungspolitik in Frankreich. In Raub und Restitution. "Arisierung" und Rückerstattung des jüdischen Eigentums in Europa, ed. Constantin Goschler and Philipp Ther, 108-33. Frankfurt am Main: Fischer Taschenbuch Verlag.

- 2007. Two Approaches to Compensation in France. In Robbery and Restitution: The Conflict Over Jewish Property in Europe, ed. Martin Dean, Constantin Goschler, and Philipp Ther, 134-54. New York: Berghahn Books.

—. 2011. Post-War Restitution Versus Present-Day Reparation in France: Towards the Disappearance of Legal and Political Dilemmas? In The Post-War Restitution of Property Rights in Europe. Comparative Perspectives, ed. Wouter Veraart and Laurens Winkel, 11-19. Amsterdam: Scientia Verlag.

Arendt, Hannah. 1975. The Origins of Totalitarianism. San Diego, CA: Harcourt Brace.

Atuahene, Bernadette. 2014. We Want What's Ours. Learning from South Africa's Land Restitution Program. Oxford: Oxford University Press.

Benhabib, Seyla. 1992. Situating the Self. Gender, Community and Postmodernism in Contemporary Ethics. New York: Routledge.

Bernstein, J. M. 1995. Recovering Ethical Life. Jürgen Habermas and the Future of Critical Theory. London: Routledge.

Bossenbroek, Martin. 2001. De Meelstreep. Terugkeer en Opvang na de Tweede Wereldoorlog. Amsterdam: Bert Bakker.

Brown, Wendy. 1995. States of Injury. Power and Freedom in Late Modernity. Princeton, NJ: Princeton University Press.

Campfens, Evelien. 2015. Sources of Inspiration: Old and New Rules for Looted Art. In Fair and Just Solutions? Alternatives to Litigation in Nazi-Looted Art Disputes: Status Quo and New Developments, ed. Evelien Campfens, 13-39. The Hague: Eleven International.

Citroen, Michal. 1999. You Are Expected by Nobody. Dutch Jews After Camps and Hiding. Utrecht: Het Spectrum (in Dutch).

Diner, Dan. 2007. Memory and Restitution: World War II as a Foundational Event in a Uniting Europe. In Restitution and Memory. Material Restoration in Europe, ed. Dan Diner and Gotthard Wunberg, 9-20. New York: Berghahn Books.

Dreyfus, Jean-Marc. 2003. Die Enteignung der Juden in Westeuropa. In Raub und Restitution. "Arisierung" und Rückerstattung des Jüdischen Eigentums in Europa, ed. Constantin Goschler and Philipp Ther, 41-57. Frankfurt am Main: Fischer Taschenbuch Verlag.

Eizenstat, Stuart. 2003. Imperfect Justice. Looted Assets, Slave Labor and the Unfinished Business of World War II. New York: Public Affairs.

Fassin, Didier, and Richard Rechtman. 2009. The Empire of Trauma. An Inquiry into the Condition of Victimhood. Princeton, NJ: Princeton University Press.

Fette, Julie. 2006. The Apology Moment. Vichy Memories in 1990s France. In Taking Wrongs Seriously: Apologies and Reconciliation, ed. Elazar Barkan and Alexander Karn, 259-85. Stanford, CA: Stanford University Press.

Hilberg, Raul. 1985. The Destruction of the European Jews. Revised and Definitive Edition. New York: Holmes \& Meier.

Lagrou, Pieter. 2000. The Legacy of Nazi Occupation. Patriotic Memory and National Recovery in Western Europe, 1945-1967. Cambridge: Cambridge University Press. 


\section{LAW \& SOCIAL INQUIRY}

Letter of the Prime Minister and the Ministers of Health, Welfare and Sport, and Finance to the Chair of the Second Chamber of Parliament. 2000. The Hague, 21 March, Dutch Parliamentary Papers 25 839, nr. 13.

Lipschits, Isaac. 2003. The Dutch Government: Discriminating Against the Survivors Through a So-Called Egalitarian Approach. In Europe's Crumbling Myths. The Post-Holocaust Origins of Today's Anti-Semitism, ed. Manfred Gerstenfeld, 180-87. Jerusalem: Jerusalem Center for Public Affairs.

Maissen, Thomas. 2005. Verweigerte Erinnerung. Nachrichtenlose Vermögen und Schweizer Weltkriegsdebatte 1989-2004. Zürich: Verlag Neue Zürcher Zeitung.

Margalit, Avishai, and Gabriel Motzkin. 1996. The Uniqueness of the Holocaust. Philosophy $\mathcal{E}^{2}$ Public Affairs 25 (1): 65-83.

Mattéoli, Jean. 2000a. Rapport Général. Mission d'Étude sur la Spoliation des Juifs de France. Paris: La Documentation Française.

2000b. Summary of the Work by the Study Mission on the Spoliation of Jews in France. Paris: La Documentation Française.

Piersma, Hinke, and Jeroen Kemperman. 2015. Openstaande rekeningen. De gemeente Amsterdam en de gevolgen van roof en rechtsherstel 1940-1950, Amsterdam: Boom.

Prost, Antoine, Rémi Skoutelski, and Sonia Étienne. 2000. Aryanisation Économique et Restitutions. Paris: La Documentation Française.

Ruppert, Christiaan. 2015. Nederlandse Akkoorden in 2000 Over Joodse Oorlogstegoeden. BMGN-Low Countries Historical Review 130 (3): 50-71.

Staal, Philip. 2008. Roesturijstaal. Speurtocht Naar de Erfenis van Joodse Oorlogswezen. Delft: Eburon.

Unfried, Berthold. 2014. Vergangenes Unrecht. Entschädigung und Restitution in Einer Globalen Perspektive. Göttingen: Wallstein Verlag.

Veraart, Wouter. 2005. Deprivation and Restitution of Property Rights During the Years of Occupation and Postwar Reconstruction of the Netherlands and in France (in Dutch). Deventer: Kluwer. 2011. Contrasting Legal Concepts of Restitution in France and the Netherlands. In The Post-War Restitution of Property Rights in Europe. Comparative Perspectives, ed. Wouter Veraart and Laurens Winkel, 21-34. Amsterdam: Scientia Verlag.

. 2015. Between Justice and Legal Closure-Looted Art Claims and the Passage of Time. In Fair and Just Solutions? Alternatives to Litigation in Nazi-Looted Art Disputes: Status Quo and New Developments, ed. Evelien Campfens, 211-21. The Hague: Eleven International.

Veraart, Wouter, and Laurens Winkel. 2011. An Introduction to Dilemmas of Post-War Restitution in Europe. In The Post-War Restitution of Property Rights in Europe. Comparative Perspectives, ed. Wouter Veraart and Laurens Winkel, 1-10. Amsterdam: Scientia Verlag.

Verheyde, Philippe. 1999. Les Mauvais Comptes de Vichy. L'Aryanisation des Entreprises Juives. Paris: Perrin.

Weil-Curiel, André. 1945. Règles de Savoir Vivre à l'Usage d'un Jeune Juif de Mes Amis. Paris: n.p.

Withuis, Jolande, and Annet Mooij. 2010. From Totalitarianism to Trauma. A Paradigm Change in the Netherlands. In The Politics of War Trauma. The Aftermath of World War II in Eleven European Countries, ed. Jolande Withuis and Annet Mooij, 193-215. Amsterdam: Aksant.

\section{STATUTES CITED}

Dutch Decree on Occupation Measures (Besluit Bezettingsmaatregelen), Staatsblad E-93 (September 17, 1944).

Dutch Decree on the Restoration of Legal Relations (Besluit Herstel Rechtsverkeer), Staatsblad E100 (September 17, 1944).

French Decree on Restitution of April 21, 1945 (Ordonnance du 21 avril 1945), Journal Officiel de la République Française (April 22, 1945). 